\title{
Anti-Leukemia Activity of Au/CuO/ZnO Nanoparticles Synthesized used Verbena officinalis Extract
}

\author{
Renata Dobrucka ${ }^{1} \cdot$ Aleksandra Romaniuk-Drapała $^{2} \cdot$ Mariusz Kaczmarek $^{3,4}$
}

Received: 18 May 2020 / Accepted: 27 July 2020 / Published online: 3 August 2020

(C) The Author(s) 2020

\begin{abstract}
As biological synthesis has become an alternative to chemical and physical methods for synthesizing nanoparticles, this work describes the synthesis of $\mathrm{Au} / \mathrm{CuO} / \mathrm{ZnO}$ nanoparticles using Verbena officinalis extract. The synthesized $\mathrm{Au} / \mathrm{CuO} / \mathrm{ZnO}$ nanoparticles were characterized using Ultraviolet-Visible, Fourier Transform-Infrared, Transmission Electron Microscopy and Atomic Force Microscopy. The influence of $\mathrm{Au} / \mathrm{CuO} / \mathrm{ZnO}$ nanoparticles on cell viability was evaluated in vitro, using the established cell line - Jurkat (ATCC® TIB-152 ${ }^{\mathrm{TM}}$ ). The Annexin V binding test confirmed the previous results of the MTT assay, which indicate that the studied complex of $\mathrm{Au} / \mathrm{CuO} / \mathrm{ZnO}$ nanoparticles has a strong cytotoxic effect on the Jurkat cell line. The type of death and the effectiveness of cell elimination depended both on the concentration of the complex and the duration of culture.
\end{abstract}

Keywords Biosynthesis · Verbena officinalis $\cdot$ Leukemia

\section{Introduction}

Recently, metal nanoparticles have been the subject of extensive studies due to the usefulness of their biological properties, benign nature and great characteristics [1]. Changes in the physical and chemical properties of this class of nanomaterials can heavily influence their applications [2]. Many scientists have focused on bimetallic and trimetallic nanoparticles, whose chemical and physical properties are different from the properties of individual metals because of combinations and interactions between the individual

Renata Dobrucka

renata.dobrucka@ue.poznan.pl

1 Department of Non-Food Products Quality and Packaging Development, Institute of Quality Science, Poznań University of Economics and Business, al. Niepodległości 10, 61-875 Poznań, Poland

2 Department of Clinical Chemistry and Molecular Diagnostics, Poznan University of Medical Sciences, 49 Przybyszewskiego St, 60-355 Poznań, Poland

3 Department of Cancer Immunology, Chair of Medical Biotechnology, Poznan University of Medical Sciences, Garbary 15 Str, 61-866 Poznan, Poland

4 Gene Therapy Laboratory, Department of Cancer Diagnostics and Immunology, Greater Poland Cancer Centre, Garbary 15 Str, 61-866 Poznan, Poland components of such nanoparticles. Nanoparticle combinations give rise to the search for and design of new materials (nanomaterials) with unique characteristics, which attracts the attention of researchers working in various engineering and academic fields [3].

There are various methods for synthesizing trimetallic nanoparticles, including microwave, co-precipitation, hydrothermal, selective catalytic reduction and micro emulsion etc. The microwave dielectric heating offers considerable advantages as it makes it possible to tailor the structural aspect by controlling the conditions of reactions [4]. Trimetallic nanoparticles are also obtained from biological synthesis [5]. Biological substrates are used in the preparation and development of bio-medically useful inorganic nanoparticles due to their non-toxic properties and environmentally friendly nature [6]. Moreover, biological synthesis is straight forward and uncomplicated, while the bioactivity of biosynthesized nanoparticles is enhanced by plant phytonutrients. Recently, with the increasing awareness of risks associated with conventional methods and the negative impact of chemical methods on the environment, green synthesis has become more significant. Even though conventional chemical methods make it possible to easily control, to a certain extent, the shape of synthesized nanoparticles, they have two major drawbacks: the cost and the application of toxic chemicals [1]. 
Plants are considered as natural capping agents for nanoparticle synthesis and microorganisms are considered as nanofactories. The intracellular and extracellular metal nanoparticles are synthesized from bacteria, fungi, algae and actinomyces. Besides methods of extracellular synthesis of silver nanoparticles, more attention is paid towards the intracellular method. Due to the presence of biologically active compounds, trimetallic $\mathrm{Au} / \mathrm{CuO} / \mathrm{ZnO}$ nanoparticles were synthesized using Verbena officinalis water extract. The use of biological synthesis using $V$. officinalis water extract to obtain trimetallic nanoparticles has not been reported in the literature. The novelty is the biological synthesis of trimetallic nanoparticles using this type of plant.

$V$. officinalis is the main species belonging to the Verbena genus of the Verbenaceae family (Verbeneae subfamily). The whole Verbenaceae family consists of about 1100 species. It includes trees, bushes and herbaceous plants. V. officinalis is naturally distributed throughout the world: in Europe, both Americas, North and Central Africa, Asia and Australia. The species grows mainly in the temperate climate zone. In Europe, it is commonly found in the Mediterranean. The main groups of secondary metabolites that determine the biological activity profiles of the raw material are iridoid glycosides, including verbenalin (verbenaloside), aucubin (verbenine) and hastatoside, as well as phenylpropanoid glycosides (caffeic acid derivatives), including verbascoside (acteoside), isoverbascoside (isoacteoside), and eukovoside [7].

\section{Materials and Methods}

\subsection{Materials}

Chemicals used in this work were purchased from Sigma-Aldrich (Poland).

\subsection{Synthesis of $\mathrm{Au} / \mathrm{CuO} / \mathrm{ZnO}$ Nanoparticles using Verbena officinalis Extract}

$\mathrm{Au} / \mathrm{CuO} / \mathrm{ZnO}$ nanoparticles were synthesized using $V$. officinalis water extract. The first stage of the study started with preparing the extract. The extract was made from $5 \mathrm{~g}$ of finely powdered $V$. officinalis, to which $100 \mathrm{ml}$ of double distilled water were added. The prepared solution was subjected to heating and vigorous stirring for $55 \mathrm{~min}$ at $90{ }^{\circ} \mathrm{C}$. During that time, three separate solutions were prepared: $5 \mathrm{mM}$ $\mathrm{HAuCl}_{4}, 5 \mathrm{mM} \mathrm{CuCl}_{2}$, and $5 \mathrm{mM} \mathrm{ZnNO}$. The obtained fresh extract was filtered through Whatman's No. 1 filter paper and combined with the prepared solutions at a 1:1:1:1 ratio. Then, the solution was stirred for $24 \mathrm{~h}$ at $55^{\circ} \mathrm{C}$. It is important to maintain a constant temperature and a stirring speed.

\subsection{Characterization of $\mathrm{Au} / \mathrm{CuO} / \mathrm{ZnO}$ Nanoparticles using Verbena officinalis Extract}

The maximum absorbance of the sample was measured by UV-Visible spectrophotometry. Ultraviolet and visible absorption spectroscopy (spectrophotometer Cary E 500) in the range of 300-600 $\mathrm{nm}$ were used to analyze the optical properties. The characterization of $\mathrm{Au} / \mathrm{CuO} / \mathrm{ZnO}$ nanoparticles involved Fourier Transform Infrared Spectroscopy analysis with Perkin Elmer Spectrum 1000 (USA), in attenuated total reflection mode and using spectral range of $4000-380 \mathrm{~cm}^{-1}$, with a resolution of $4 \mathrm{~cm}^{-1}$. FTIR analysis was used to determine the binding properties of $\mathrm{Au} / \mathrm{CuO} / \mathrm{ZnO}$ nanoparticles synthesized using V.officinalis extract. Fourier transform infrared spectroscopy (FTIR) was used to characterize $\mathrm{Au} / \mathrm{CuO} / \mathrm{ZnO}$ nanoparticles synthesized using $V$. officinalis extract. The shape, size and microstructures of $\mathrm{Au} / \mathrm{CuO} / \mathrm{ZnO}$ nanoparticles synthesized using $V$. officinalis extract were determined by means of a Transmission electron microscope JEOL JEM 1200 EXII operating at $80 \mathrm{kV}$. The study was conducted using the atomic force microscope INTEGRA SPECTRA SOLAR of NT-MDT brand, and measurement tips dedicated for NSGO1 high-resolution measurements, in the tapping mode. The resonance frequency of the tips ranged from 87 to $230 \mathrm{kHz}$. The force constant ranged from 1.45 to $15.1 \mathrm{~N} / \mathrm{m}$. The scanning area was $10 \mu \mathrm{m} \times 10 \mu \mathrm{m}$, with $1000 \times 1000$ scanning points. The picture of $\mathrm{Au} / \mathrm{CuO} /$ $\mathrm{ZnO}$ nanoparticles synthesized using $V$. officinalis extract was made by means of Scanning electron microscopy (SU3500), Hitachi.

\subsection{Evaluation of Cytotoxic Activity of $\mathrm{Au} / \mathrm{CuO} / \mathrm{ZnO}$ Nanoparticles using Verbena officinalis Extract}

The impact of $\mathrm{Au} / \mathrm{CuO} / \mathrm{ZnO}$ nanoparticles on cell viability was evaluated in vitro, using the established cell line-Jurkat (ATCC $®$ TIB-152 ${ }^{\mathrm{TM}}$ ) obtained from American Type Culture Collection (Manassas, VA, USA). Acute T Cell Leukemia cell line-Jurkat was cultured in the RPMI-1640 medium with $10 \%$ of fetal bovine serum (FBS), $50 \mathrm{U} / \mathrm{mL}$ of penicillin, $100 \mu \mathrm{g} / \mathrm{mL}$ of streptomycin, and $25 \mu \mathrm{g} / \mathrm{mL}$ of Amphotericin B. Cells were distributed in the amount of $5 \times 10^{5}$ cells per well, and cultured in an incubator on 24-well plastic plates with flat bottom (TC-PLATE 24 well, Greiner) at $37{ }^{\circ} \mathrm{C}, 5 \% \mathrm{CO}_{2}$ atmosphere with increased humidity. $\mathrm{Au} /$ $\mathrm{CuO} / \mathrm{ZnO}$ nanoparticles were added at three different concentrations: $1 \mu \mathrm{M}, 10 \mu \mathrm{M}$, and $100 \mu \mathrm{M}$. Samples without the addition of $\mathrm{Au} / \mathrm{CuO} / \mathrm{ZnO}$ nanoparticles served as controls. All the tested samples, both Jurkat cells, and PBMC were cultured for the period of 24,48 and $72 \mathrm{~h}$. 


\subsection{PBMC Separation}

Peripheral blood samples from voluntary donors were collected to test tubes with heparin. Then, blood was mixed at a 1:1 ratio with sterile Phosphate-Buffered Saline (PBS), and placed on the Histopaque ${ }^{\circledR}-1077$ (Sigma-Aldrich) solution. Histopaque ${ }^{\circledR}-1077$ is a polysucrose and sodium diatrizoate solution with the density of $1.077 \mathrm{~g} / \mathrm{mL}$, which enables the separation of viable lymphocytes and other mononuclear cells from the other components of whole peripheral blood (thrombocytes, erythrocytes, granulocytes). After $20 \mathrm{~min}$ of centrifugation at $1500 \mathrm{rpm}$ in RT, the interphase containing peripheral blood mononuclear cells (PBMC) was collected and transferred onto 24-well culture plates. Then, PBMC cells were cultured in RPMI 1640 media with $10 \%$ of FBS and $1 \%$ of antibiotic/antimycotic mixture, as described above for the Jurkat cell line. Following the culture in the presence of the studied $\mathrm{Au} / \mathrm{CuO} / \mathrm{ZnO}$ nanoparticles, PBMC were subjected to cell cycle assessment.

\subsection{MTT Test (Cell Viability Assay)}

The Jurkat cell line was incubated with different concentrations of the tested substance for 24 and $48 \mathrm{~h}$. The inhibition of cell growth caused by nanoparticles was determined by MTT assay. The viability percentage of Jurkat cells was specified in reference to control cells cultured without the addition of the studied nanoparticles. The mean standard deviation $( \pm S D)$ was calculated with the use of Microsoft Excel software (Microsoft, Redmond, WA, USA) in three independent experiments repeated twice. Half-maximal inhibitory concentration (IC50) means the concentration of $\mathrm{Au} / \mathrm{CuO} / \mathrm{ZnO}$ nanoparticles that causes a $50 \%$ reduction in the number of cells compared to non-stimulated controls. IC50 values were calculated for each time point of culture using CalcuSyn software (BIOSOFT, Cambridge, United Kingdom). Cell viability was assessed using 3-(4,5-dimethylthiazol-2-yl)-2,5-diphenyltetrazolium bromide (MTT) in accordance with the manufacturer's instructions. Jurkat cells $\left(5 \times 10^{3}\right)$ were cultured with the addition of $\mathrm{Au} / \mathrm{CuO} /$ $\mathrm{ZnO}$ nanoparticles at the following concentrations: $0.1 ; 0.5$; $1 ; 2 ; 4 ; 6 ; 8 ; 10 ; 50$ and $100 \mu \mathrm{mol}$. The studied cells were suspended in the culture medium in which the cell line was cultured. After 24, 48 and $72 \mathrm{~h}$ of incubation, $10 \mu \mathrm{l}$ of the MTT solution $(5 \mathrm{mg} / \mathrm{mL})$ were added to each well for $4 \mathrm{~h}$. In order to release formazan crystals from the cells, $100 \mu \mathrm{l}$ of a solubilizing solution were added to the samples, which were then incubated overnight. Then, optical density (OD) values of the samples were measured with a spectrophotometer Multiscan FC (ThermoScientific, Champaign, IL, USA) in the wavelength of $570 \mathrm{~nm}$. Samples of the studied compounds mixed with MTT without the test cells were used as negative controls. In order to reduce test error, the background control absorbance level was subtracted from the absorbance of tested and control cells. The viability of the control group was determined as $100 \%$. Test results were given as Relative Viability of Cells (RVC), which is defined as the ratio between the absorbance value of cells cultured in the presence of the tested nanoparticles and the absorbance value of control samples. The RVC was calculated on the basis of the formula described below, were (a) stands for the absorbance of the tested sample; (b) stands for the absorbance of the blank control sample (pure medium without cells); and (c) stands for the absorbance of control cells without the addition of $\mathrm{Au} / \mathrm{CuO} / \mathrm{ZnO}$.

$\operatorname{RVC}(\%)=[(a-b) /(c-b)] \times 100$

The IC50 index was calculated as well. The IC50 value shows the concentration of tested substances which is needed to inhibit, in vitro, the biological activity of cells by $50 \%$.

\subsection{Evaluation of Apoptosis with Annexin V}

The impact of $\mathrm{Au} / \mathrm{CuO} / \mathrm{ZnO}$ nanoparticles on the viability of the Jurkat cell line was also evaluated in terms of the initiation of apoptosis or necrosis. The evaluation of apoptotic or necrotic death was carried out using a commercially available FITC Annexin V apoptosis detection kit (BD Pharmingen), in accordance with the manufacturer's protocol. Analogously to the MTT assay, cells were cultured in the presence of $1 \mu \mathrm{M}, 10 \mu \mathrm{M}$, and $100 \mu \mathrm{M}$ of $\mathrm{Au} / \mathrm{CuO} / \mathrm{ZnO}$ nanoparticles for 24 and $48 \mathrm{~h}$. The test was performed as follows: first, cells were suspended in $100 \mu$ of Annexin buffer $(1 \times)$ in the amount of $1 \times 10^{5}$ cells. Next, $5 \mu \mathrm{l}$ of propidium iodide (PI) and $5 \mu \mathrm{l}$ of Annexin V conjugated with fluorescein (FITC) were added to the samples. After $15 \mathrm{~min}$ of incubation in the dark, $400 \mu \mathrm{l}$ of Annexin buffer $(1 \times)$ were added to each test tube. Stained samples were acquired with FACS Canto flow cytometer (Becton Dickinson), and results were analyzed with FACS Diva software (Becton Dickinson). Cells were defined as early apoptotic, late apoptotic or necrotic based on the proportion between FITC and/or PI fluorescence.

\subsection{Flow Cytometry of Cell Cycle}

In order to evaluate the cell cycle of the Jurkat cell line, cells were placed in the wells in the amount of $5 \times 10^{5}$ cells per well. The cell line was cultured for 24,48 and $72 \mathrm{~h}$ in the presence of the tested nanoparticles at the concentration of 1,10 and $100 \mu \mathrm{mol}$. Cells cultured in the medium without the tested substance were used as control samples. The cell cycle of PBMC cells exposed to the studied nanoparticles was evaluated as well. The respective cell cycle phases were assessed using propidium iodide (PI). The measurement of 
the percentage of cells in the $S$ phase of the cell cycle makes it possible to estimate the proliferative activity of the population. Moreover, the evaluation of the cell cycle makes it possible to determine the percentage of dead cells and cells in the G2/M phase. The distribution of cell cycle phases was examined by calculating the mean fluorescence intensity (MFI) of PI. After the tests, cells were transferred from plates to test tubes and suspended in the permeabilization buffer-BD Perm/Wash ${ }^{\mathrm{TM}}$ (BD Biosciences). After incubation for 30 min at $4{ }^{\circ} \mathrm{C}$, cells were centrifuged and suspended in a PBS buffer with $10 \mathrm{mg} / \mathrm{mL}$ of propidium iodide (Sigma) and $100 \mu \mathrm{g} / \mathrm{mL}$ of RNase enzyme (Boehringer Mannheim). After further incubation for $30 \mathrm{~min}$ at $4{ }^{\circ} \mathrm{C}$, stained samples were acquired with FACS Canto flow cytometer (Becton Dickinson, USA), and analyzed with FACS Diva Software (Becton Dickinson, USA).

\section{Results and Discussion}

\subsection{UV-VIS Studies of Au/CuO/ZnO Nanoparticles}

In the UV-Visible study, UV-Vis spectroscopy was used to monitor the formation rate of nanoparticles. In this study, the absorbance of the solution was measured in a wavelength range of $200-800 \mathrm{~nm}$. Figure 1 presents the UV-Visible spectra of trimetallic nanoparticles after reaction at $55^{\circ} \mathrm{C}$ for $12 \mathrm{~h}, 18$ and $24 \mathrm{~h}$ and Verbena officinalis extract. After $24 \mathrm{~h}$, there were clearly visible peaks at $620 \mathrm{~nm}$ and $300 \mathrm{~nm}$, which indicated the emergence of nanoforms of the salts used in the study. The UV absorption spectrum determined the absorption band below $400 \mathrm{~nm}$ is characteristic of $\mathrm{ZnO}$ nanoparticles [8]. The studies of Wahaba et al. [9] where absorption peak at $364 \mathrm{~nm}$ which indicates the presence of pure $\mathrm{ZnO}$ nanoparticles. The absorption peak of $\mathrm{ZnO}$ nanoparticles below $400 \mathrm{~nm}$ obtained in the range of $373 \mathrm{~nm}$ [10], $375 \mathrm{~nm}$ [11] and $370 \mathrm{~nm}$ respectively [12]. Moreover, a change in color visually confirmed the formation of trimetallic nanoparticles. After the extract was mixed with metal nanoparticle precursors, the solution rapidly changed its color from light beige to dark beige (Fig. 2). Such a visible change of color confirms the reduction of metals to the nanoform. The similar studies conducted Paul et al. [8] and Suwannarat et al. [13], which synthesized $\mathrm{Ag} / \mathrm{Au} / \mathrm{Pd}$ nanoparticles for reduction of 4-nitrophenol.

\subsection{Fourier Transform Infrared Spectroscopy (FTIR) Studies of Au/CuO/ZnO Nanoparticles}

The results of the FTIR analysis of $\mathrm{Au} / \mathrm{CuO} / \mathrm{ZnO}$ nanoparticles synthesized using Verbena officinalis extract are presented in Fig. 3. The FTIR spectra of the extract showed major absorption bands at $3273 \mathrm{~cm}^{-1}, 2107 \mathrm{~cm}^{-1}$, $1635 \mathrm{~cm}^{-1}, 418 \mathrm{~cm}^{-1}, 385 \mathrm{~cm}^{-1}$ and $383 \mathrm{~cm}^{-1}$. The peak at $3273 \mathrm{~cm}^{-1}$ mainly corresponds to symmetrical stretching of $\mathrm{H}_{2} \mathrm{O}$. The peak which appeared at $2107 \mathrm{~cm}^{-1}$ may indicate the presence of an alkynes group. The most intense band at $1635 \mathrm{~cm}^{-1}$ represents $\mathrm{C}=\mathrm{O}$ vibrations typical of flavonoid structure (but also would have contribution of the scissoring deformation of $\mathrm{H}_{2} \mathrm{O}$ ). The peaks at $418 \mathrm{~cm}^{-1}, 385 \mathrm{~cm}^{-1}$ and $383 \mathrm{~cm}^{-1}$ are related to anti-symmetric stretching mode of the surface bridging oxide formed by condensation of the adjacent surface hydroxyl groups. The results confirm that V. officinalis contains biologically active compounds.

According to the literature, V. officinalis herb extracts contain numerous flavonoids, such as kaempferol, luteolin, apigenin, scutellarein and pedalitin. The biological activity of $V$. officinalis is highly influenced by the presence
Fig. 1 UV-Visible spectra of $\mathrm{Au} / \mathrm{CuO} / \mathrm{ZnO}$ nanoparticles and V.officinalis extract

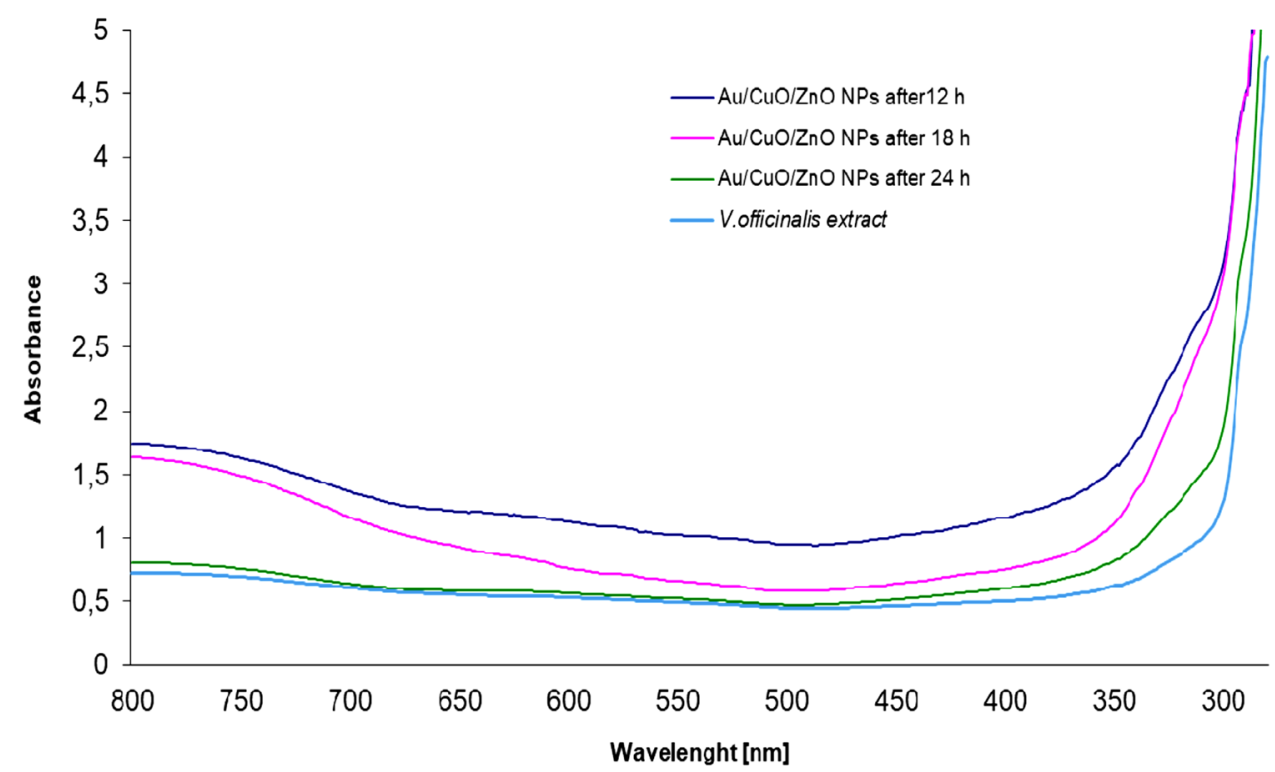


Fig. 2 Solution before (a) and after reaction at $55^{\circ} \mathrm{C}(\mathbf{b})$
A

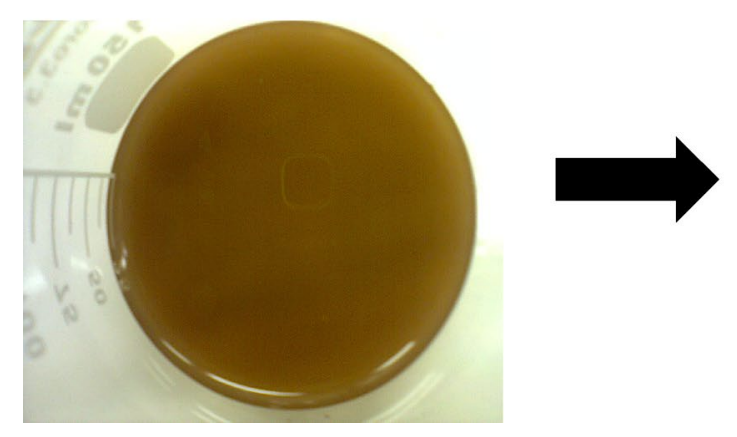

B

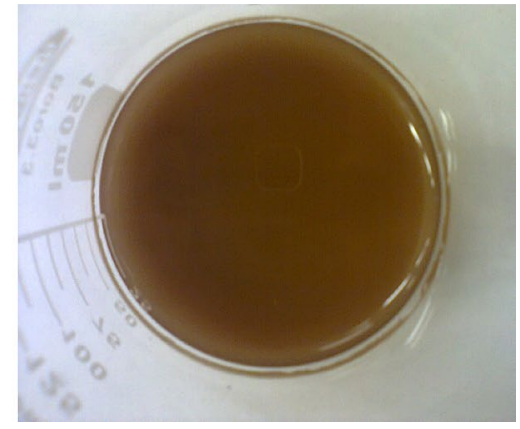

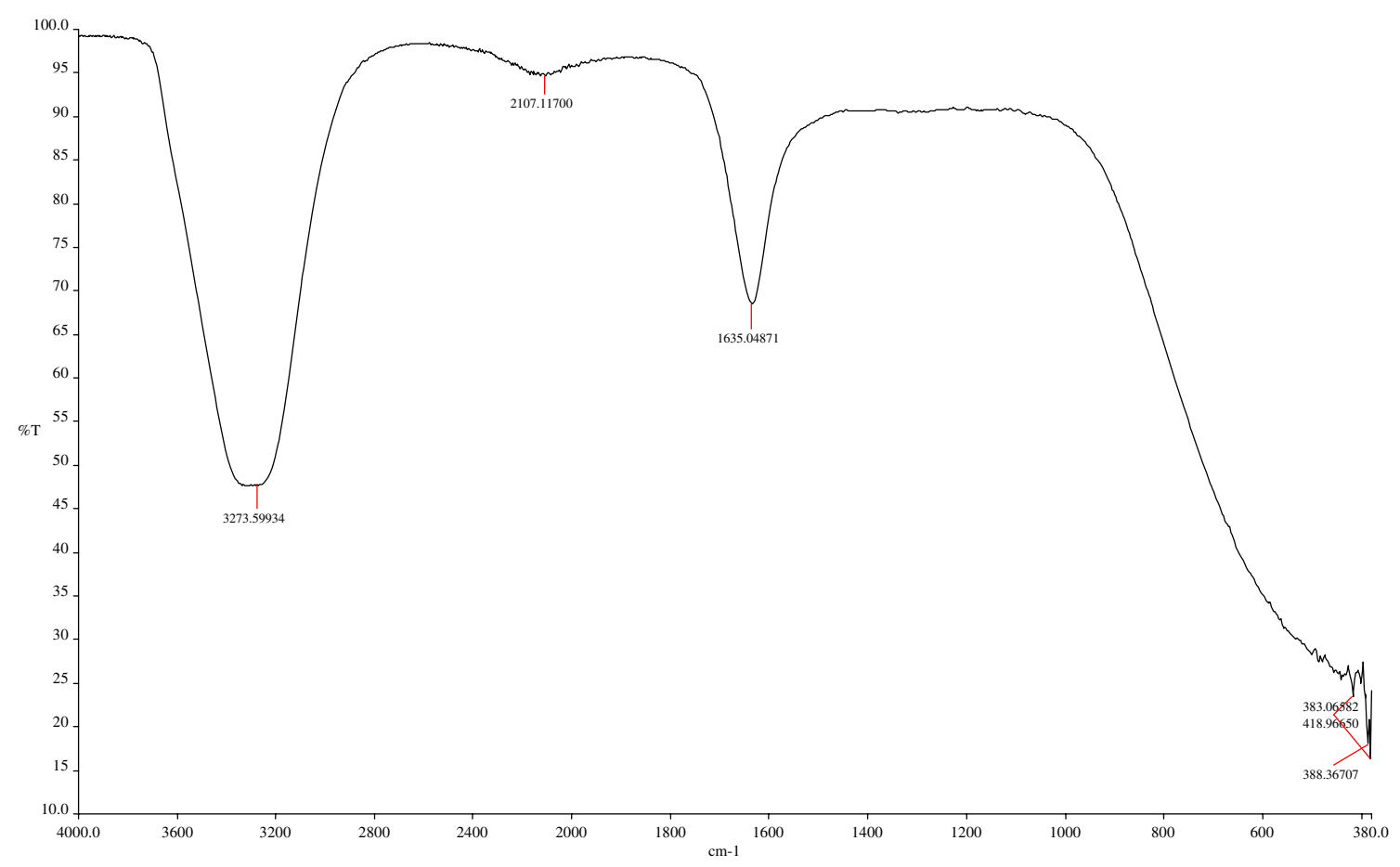

Fig. 3 FTIR spectra of the $\mathrm{Au} / \mathrm{CuO} / \mathrm{ZnO}$ nanoparticles synthesized using V.officinalis extract

of phenolic acids: chlorogenic, ferulic, protocatechuic, rosmarinic acid and dicaffeoylquinic acid derivatives [7]. Phenolic acids have strong antioxidant properties, which, as shown by scientists, are chemical structure-dependent. The antioxidant activity is related to the number of hydroxyl groups in the particle as well as their degree of esterification. If only one hydroxyl group is present in the compound, its antioxidant properties are strengthened by one or two methoxy groups in the ring. The antioxidant properties of phenolic acids are further stabilized by an alkyl group or a methoxy group, i.e. a group that contains electron donors, introduced in the ortho- position.

The herb of $V$. officinalis contains essential oil with about 40 compounds, the majority of which are monoterpenes (such as limonene, citral, cineole, carvone) [14]. Other groups of terpene compounds characteristic of the oil are diterpenes (carnosol, carnosic acid, rosmanol, isorosmanol) and triterpenes (ursolic acid and its derivatives). The herb of $V$. officinalis also contains carbohydrates such as d-Galacturonic acid, arabinose, galactose, rhamnose, xylose, mannose or glucose. Moreover, the main constituents of $V$. officinalis include iridoid glycosides: verbenalin (verbenaloside), aucubin (verbenin) and hastatoside, and phenylpropanoid glycosides: verbascoside (acteoside, eucovoside) and isoverbascoside (isoacteoside) [15]. Figure 4 shows the chemical structure of active compounds in V. officinalis: (A) verbenalin, (B) aucubin, (C) hastatoside, (D) isoverbascoside. 
Fig. 4 The chemical structure of active compounds in $V$. officinalis $\mathbf{a}$ verbenalin, $\mathbf{b}$ aucubin, $\mathbf{c}$ hastatoside, $\mathbf{d}$ isoverbascoside<smiles>[2H]O[C@H]1[C@H](O[2H])[C@@H](OO)[C@H](O[C@@H]2OC=C(C(=O)OC)[C@@H]3C(=O)CC[C@@H]23)O[C@@H]1CO</smiles><smiles>[2H]O[C@@H]1[C@@H](CO)OC(O[C@@H]2OC=C[C@H]3[C@@H](O)CC(CO)[C@@H]23)[C@H](O)[C@H]1O[2H]</smiles>

A<smiles>[2H]O[C@@H]1[C@@H](CO)O[C@@H](O[C@@H]2OC=C(C(=O)OC)[C@@]3(O)C(=O)C[C@H](C)[C@H]23)[C@H](O)[C@H]1O</smiles>

C
B

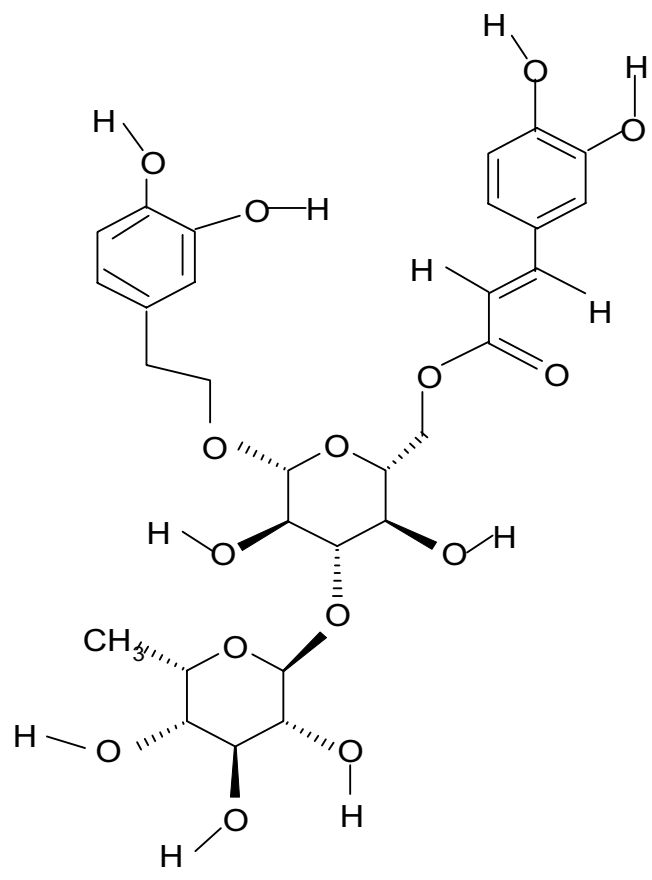

D

\subsection{Atomic Force Microscopy (AFM) Studies of Au/ CuO/ZnO Nanoparticles}

The size of the synthesized $\mathrm{Au} / \mathrm{CuO} / \mathrm{ZnO}$ nanoparticles was determined by means of Atomic force microscopy. The obtained nanoparticles were spherical in shape and $35 \mathrm{~nm}$ in size. There were also observed single agglomerates of particles of about $50 \mathrm{~nm}$. AFM microscopes can be used to carry out topographic measurements and to determine certain mechanical properties of the samples, such as elasticity, adhesion force and friction. Figure 5 presents the AFM image of the $\mathrm{Au} / \mathrm{CuO} / \mathrm{ZnO}$ nanoparticles with the topography of (A) (C) $10 \mu \mathrm{m} \times 10 \mu \mathrm{m}$, (B) $3 \mu \mathrm{m} \times$ $3 \mu \mathrm{m}$, (D) $3 \mu \mathrm{m} \times 3 \mu \mathrm{m}$ with the profile.

\subsection{Transmission Electron Microscope Analysis (TEM) Studies of Au/CuO/ZnO Nanoparticles}

TEM images were used to characterize the structure of $\mathrm{Au} /$ $\mathrm{CuO} / \mathrm{ZnO}$ nanoparticles. As indicated by their morphologies, the majority of the synthesized trimetallic nanoparticles were spherical in shape. Figure 6 shows images of the synthesized $\mathrm{Au} / \mathrm{CuO} / \mathrm{ZnO}$ nanoparticles with the following scale bars: (A), (B) $100 \mathrm{~nm}$; and (C), (D) $200 \mathrm{~nm}$. 


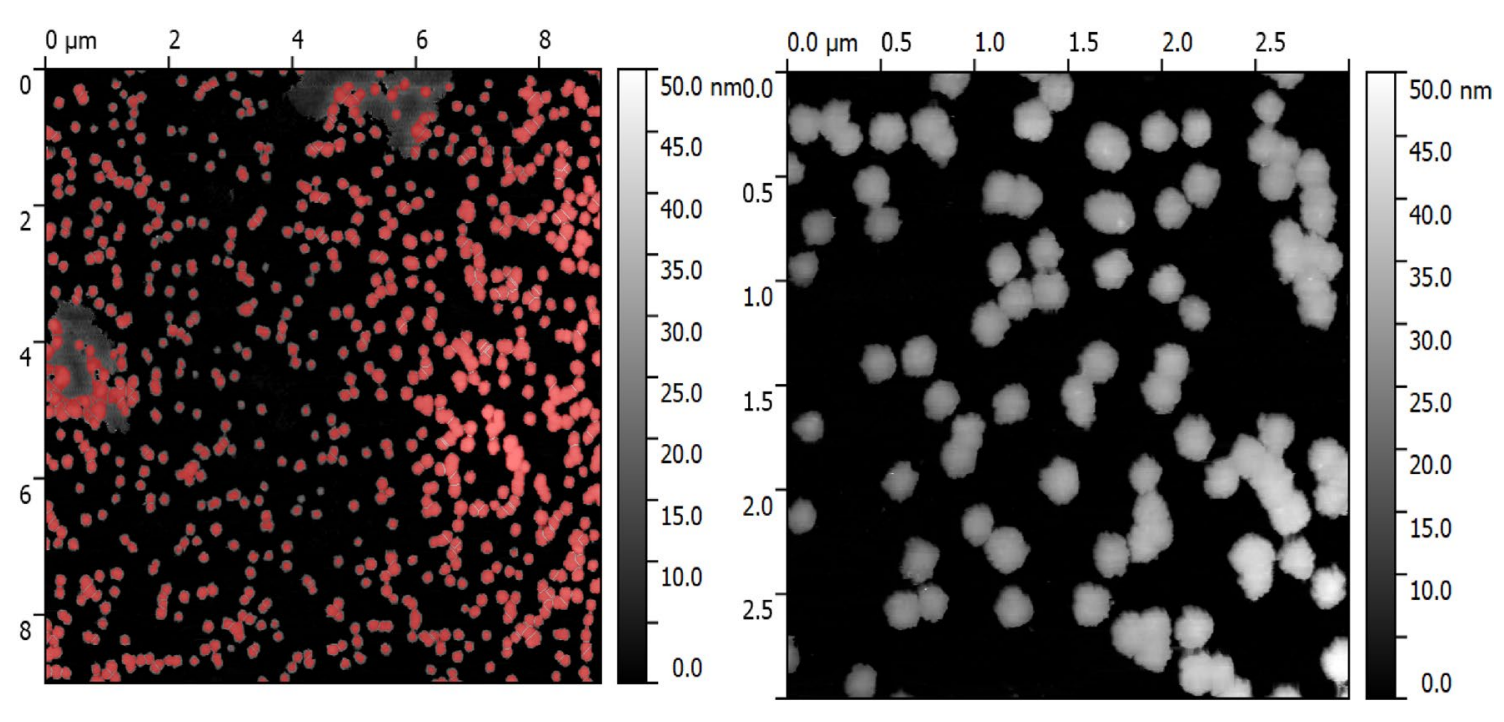

A

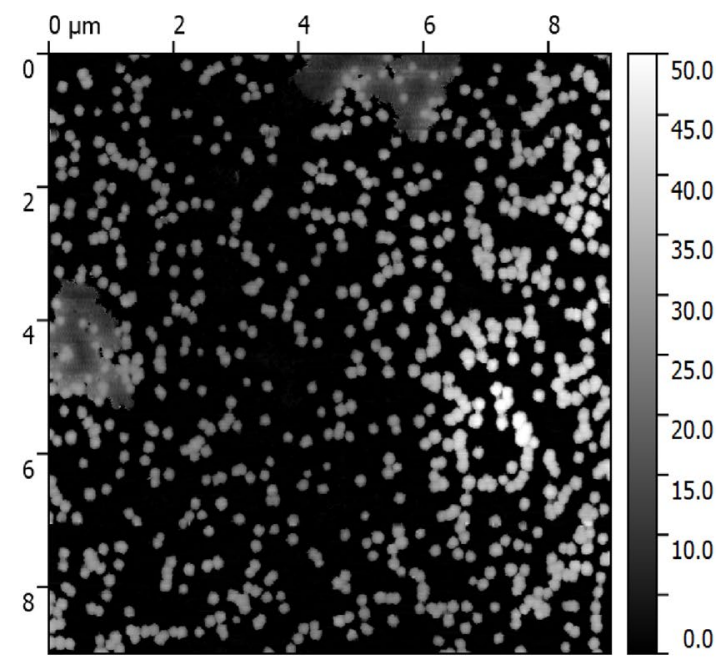

C
B

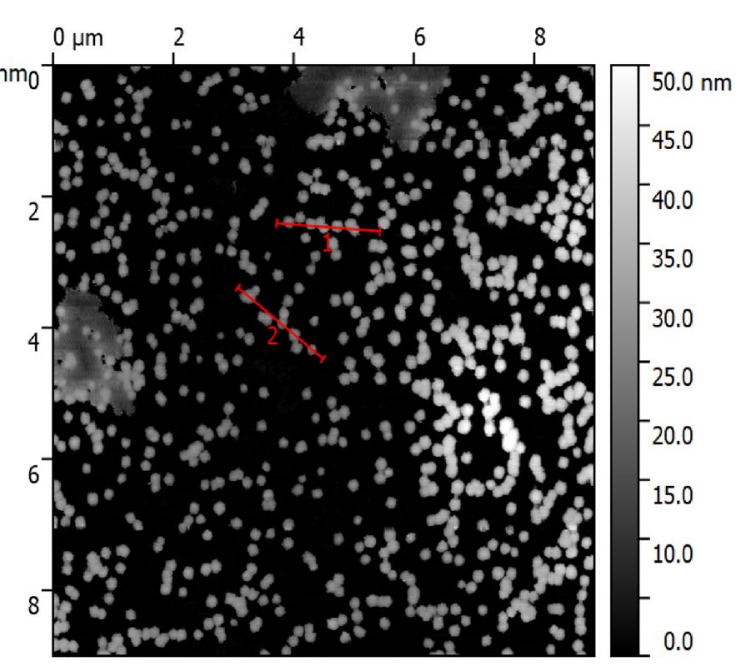

D

Fig. 5 AFM image of the $\mathrm{Au} / \mathrm{CuO} / \mathrm{ZnO}$ nanoparticles synthesized using V.officinalis extract

\subsection{Cytotoxic Activity of Au/CuO/ZnO Nanoparticles Synthesized using Verbena officinalis Extract}

\subsubsection{MTT Assay}

Leukemia is a heterogeneous group of diseases that involve malignant cloning and proliferation of blood progenitor cells. These cells develop primarily in the bone marrow (BM), from which they can circulate to peripheral hematopoietic tissues. Leukemia causes certain systemic symptoms such as anemia and bleeding, and it increases the risk of infections that threaten human life [16]. The search for new therapeutic solutions encourages the use of tools associated with nanotechnology. Metal nanoparticles possess excellent physical and chemical properties, which have been successfully utilized in several technological and biomedical fields [17]. For a long time, they have been applied in studies on various types of cancer, including liver [18], gastric [19], lung cancer [20] or glioma [21]. In the literature, there are information about the anticancer activity of metal nanoparticles such as: $\mathrm{CuO}[22,23], \mathrm{ZnO}[23]$ or $\mathrm{Au}$ $[21,24,25]$. In this work, anticancer effect of trimetallic $\mathrm{Au} /$ $\mathrm{CuO} / \mathrm{ZnO}$ nanoparticles obtained from biological synthesis was studied. The cytotoxicity of $\mathrm{Au} / \mathrm{CuO} / \mathrm{ZnO}$ nanoparticles was measured by MTT assay. The impact of those nanoparticles on the viability of the Jurkat cell line was determined using ten model concentrations: $0.1 ; 0.5 ; 1 ; 2 ; 4 ; 6 ; 8$; and 


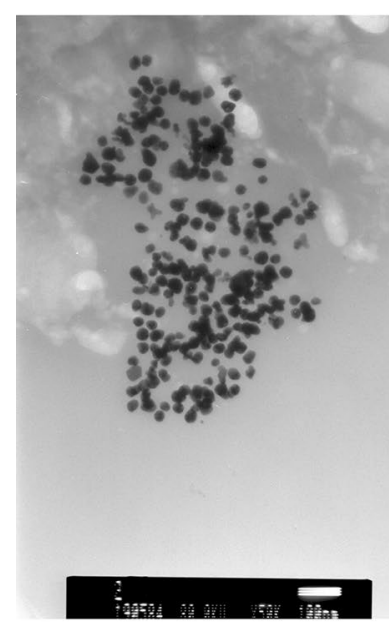

A

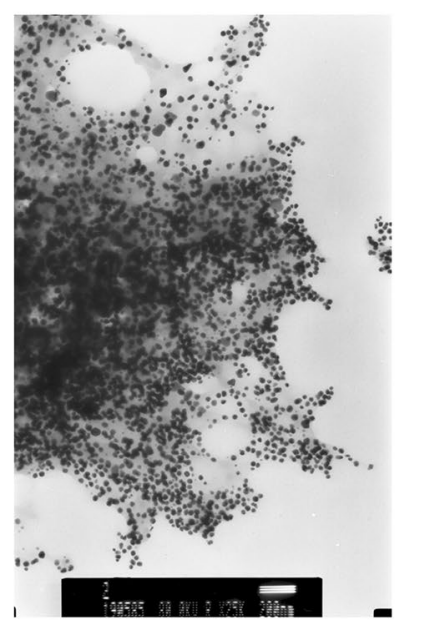

C

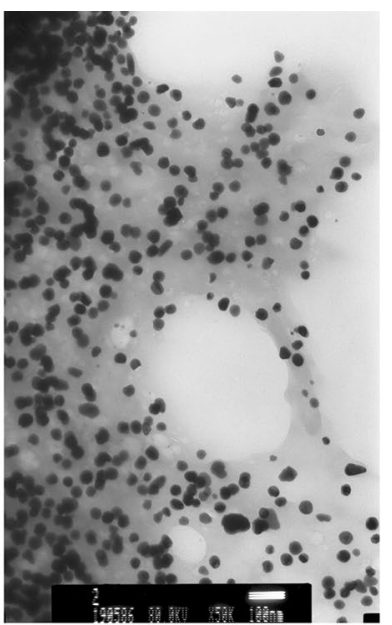

B

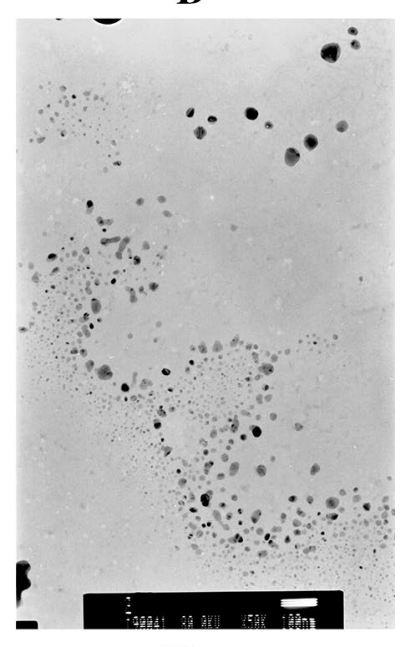

D
Fig. 6 TEM image of the $\mathrm{Au} / \mathrm{CuO} / \mathrm{ZnO}$ nanoparticles synthesized using $V$. officinalis extract
$10 \mu$ mol. The cultures were carried out for 24,48 and $72 \mathrm{~h}$. Control cells were cultured without the addition of nanoparticles. The analysis showed that cell viability rapidly reduced in the range of $80-20 \%$ at the concentration of $0.1-4 \mu \mathrm{mol}$. At the concentration of $6 \mu \mathrm{mol}$, the relative cell viability value was close to zero. IC50 was $1.08 \mu \mathrm{mol}$ for the culture carried out for $24 \mathrm{~h} ; 0.64 \mu \mathrm{mol}$ for $48 \mathrm{~h}$; and $0.39 \mu \mathrm{mol}$ for $72 \mathrm{~h}$ (Fig. 7).

\subsubsection{Annexin V Binding Test}

The Annexin V binding test was carried out to determine the mechanism of Jurkat cell elimination by the $\mathrm{Au} / \mathrm{CuO} / \mathrm{ZnO}$ nanoparticle complex. This test uses the ability of Annexin $\mathrm{V}$ to bind to phosphatidylserine residues externalized to cell membrane surface by apoptotic cells, and the penetration of cells by propidium iodide (PI) through the discontinuous cell membranes of necrotic cells. The simultaneous use of fluorochrome-labeled Annexin V and propidium iodide makes it possible to differentiate between viable and dead cells as well as identify cells in the state of early apoptosis, late apoptosis and necrosis (Fig. 8).

In order to perform the test, Jurkat cells were exposed to the complex of $\mathrm{Au} / \mathrm{CuO} / \mathrm{ZnO}$ nanoparticles at the concentration of 1,10 and $100 \mu \mathrm{mol}$ and assessed at 24 and $48 \mathrm{~h}$ of culture. The Annexin V binding test confirmed the previous results of the MTT assay, which indicate that the studied complex of $\mathrm{Au} / \mathrm{CuO} / \mathrm{ZnO}$ nanoparticles has a strong cytotoxic effect on the Jurkat cell line. The type of death and the effectiveness of cell elimination depended both on the concentration of the complex and the duration of culture. Within the first $24 \mathrm{~h}$, over $80 \%$ of cells cultured in the presence of $\mathrm{Au} / \mathrm{CuO} / \mathrm{ZnO}$ nanoparticles at the concentration of $10 \mu \mathrm{mol}$ exhibited the signs of late apoptosis, and about $60 \%$ of cells cultured in the presence of $\mathrm{Au} / \mathrm{CuO} / \mathrm{ZnO}$ nanoparticles at the concentration of 100

\begin{tabular}{|cc|}
\hline \multicolumn{3}{|c|}{$\mathrm{Au} / \mathrm{CuO} / \mathrm{ZnO}$ - NP } \\
\hline & $\mathrm{IC}_{50}(\mu \mathrm{M}) \pm$ SD $^{*}$ \\
\hline $24 \mathrm{~h}$ & $1.07764 \pm 1.4740$ \\
\hline $48 \mathrm{~h}$ & $0.64518 \pm 1.1772$ \\
\hline $72 \mathrm{~h}$ & $0.39085 \pm 1.2995$ \\
\hline
\end{tabular}

*values are means $\pm S D(n=3)$

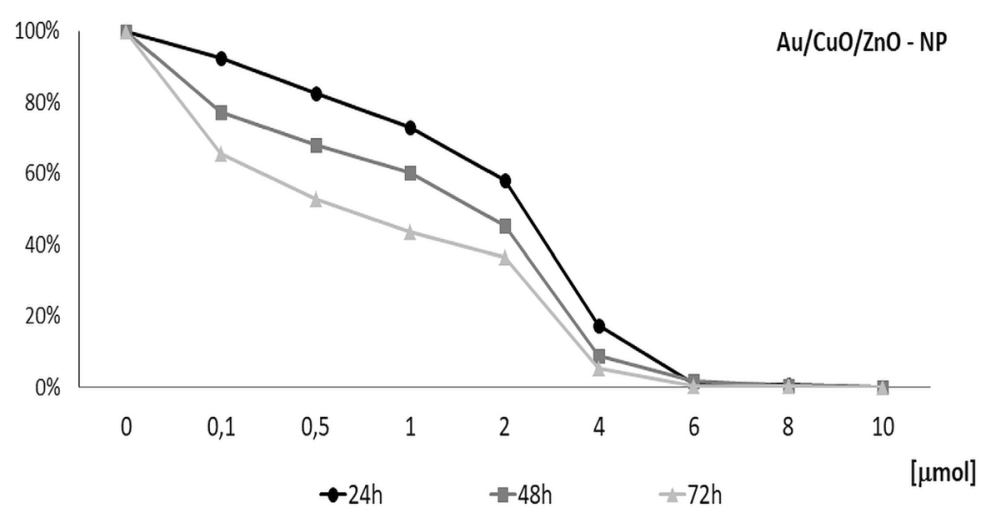

Fig. 7 Relative viability of the Jurkat cell line cultured for 24,48 and $72 \mathrm{~h}$ in the presence of $\mathrm{Au} / \mathrm{CuO} / \mathrm{ZnO}$ nanoparticles at different concentrations. The table presents the IC50 values for different culture times 
Fig. 8 Histograms of the Mean Fluorescence Intensity of FITCconjugated Annexin V and propidium iodide (PI) during the Annexin V binding test carried out for Jurkat cells cultured in the presence of $\mathrm{Au} / \mathrm{CuO} / \mathrm{ZnO}$ nanoparticles at 24 and $48 \mathrm{~h}$ of culture

$\mu$ mol underwent necrosis. At 48 h of culture, over $80 \%$ of cells cultured in the presence of the tested substance at the concentration of $100 \mu \mathrm{mol}$ showed the sings of necrosis. When the culture time was extended to $48 \mathrm{~h}$, even at the concentration of $1 \mu \mathrm{mol}$ the amount of cells in the state of late apoptosis was about $50 \%$. The mortality level of control cells during the test did not exceed $20 \%$ (Fig. 9).

\section{Time of cell culture}

$24 \mathrm{~h}$

$48 \mathrm{~h}$

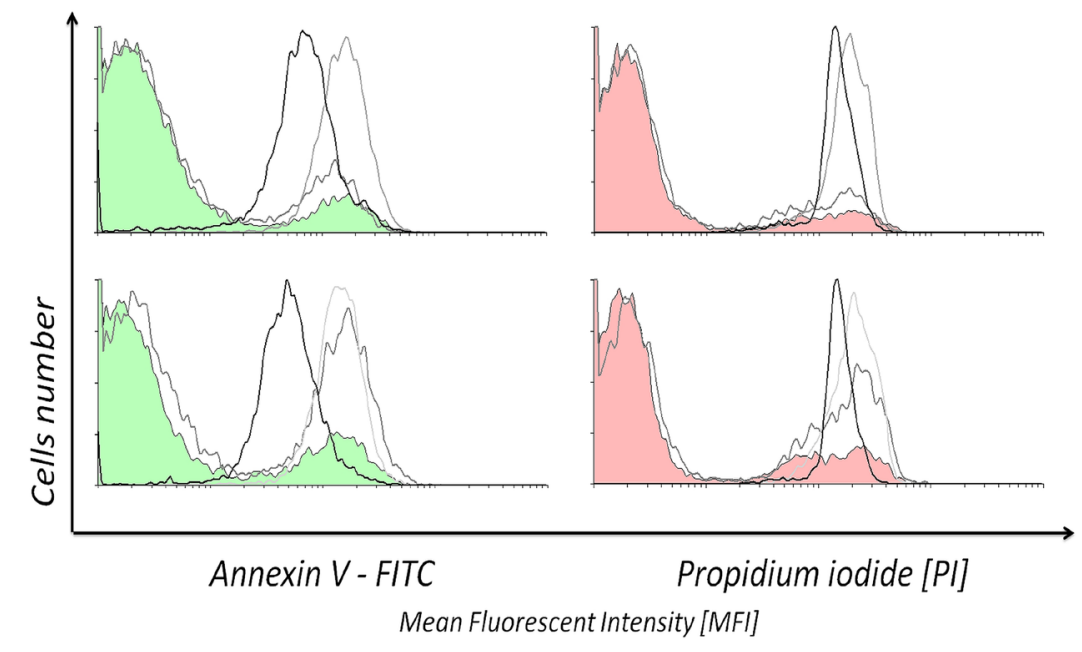

control $0 \mu \mathrm{M}-1 \mu \mathrm{M}-10 \mu \mathrm{M}-100 \mu \mathrm{M}$

\subsubsection{Assessment of Cell Cycle}

The cell cycle of the Jurkat cell line stimulated by $\mathrm{Au} / \mathrm{CuO} /$ $\mathrm{ZnO}$ nanoparticles was assessed using the fluorescent properties of propidium iodide. For this purpose, cells were cultured for 24,48 and $72 \mathrm{~h}$ with the addition of $\mathrm{Au} / \mathrm{CuO} / \mathrm{ZnO}$ nanoparticle complexes at the concentration of 1,10 and $100 \mu \mathrm{mol}$ (Fig. 10).

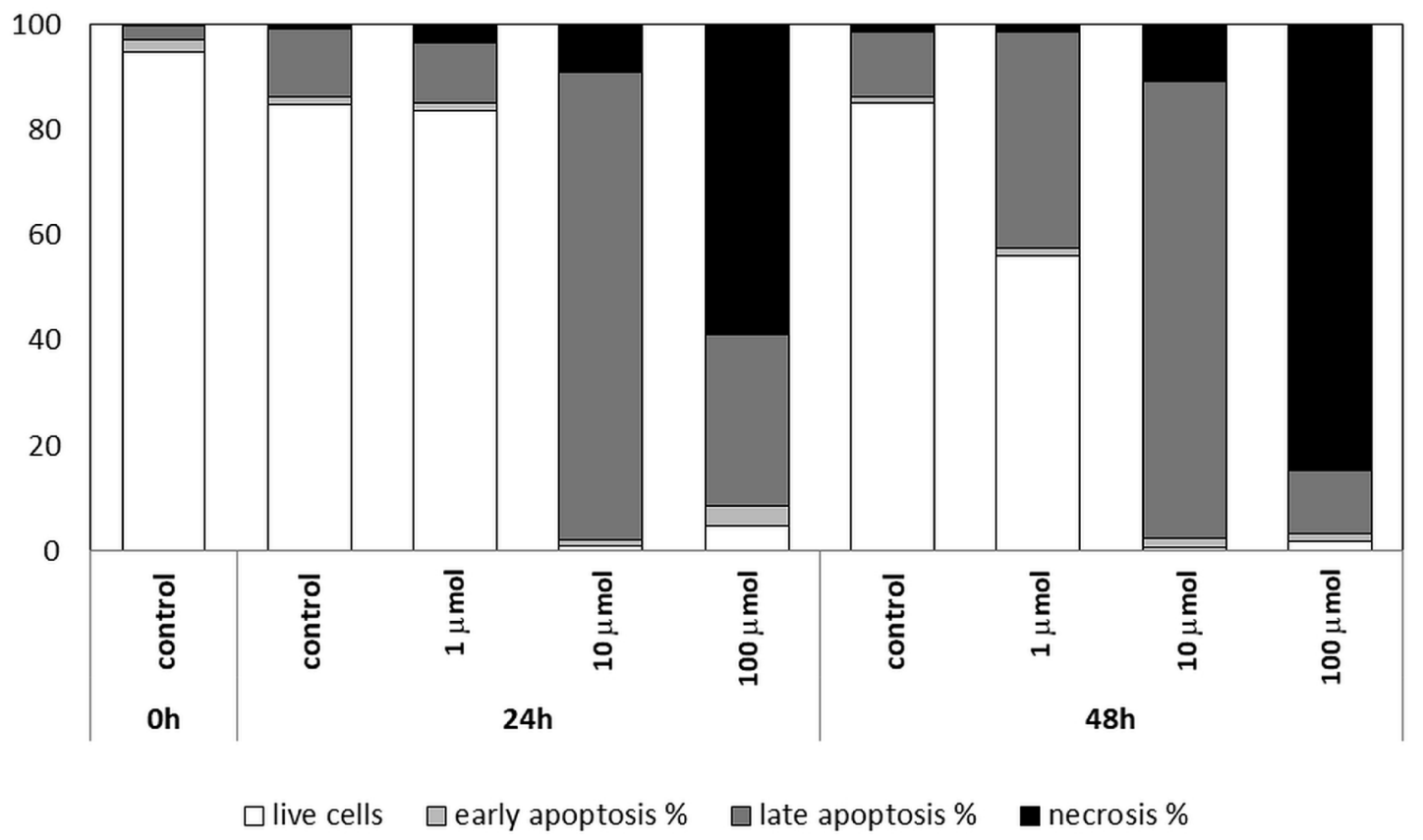

Fig. 9 Percentages of Jurkat cells cultured for 24 and $48 \mathrm{~h}$ in the presence of different concentrations of Au/CuO/ZnO nanoparticles synthesized using Verbena officinalis extract, showing a state of early apoptosis, late apoptosis and necrosis 


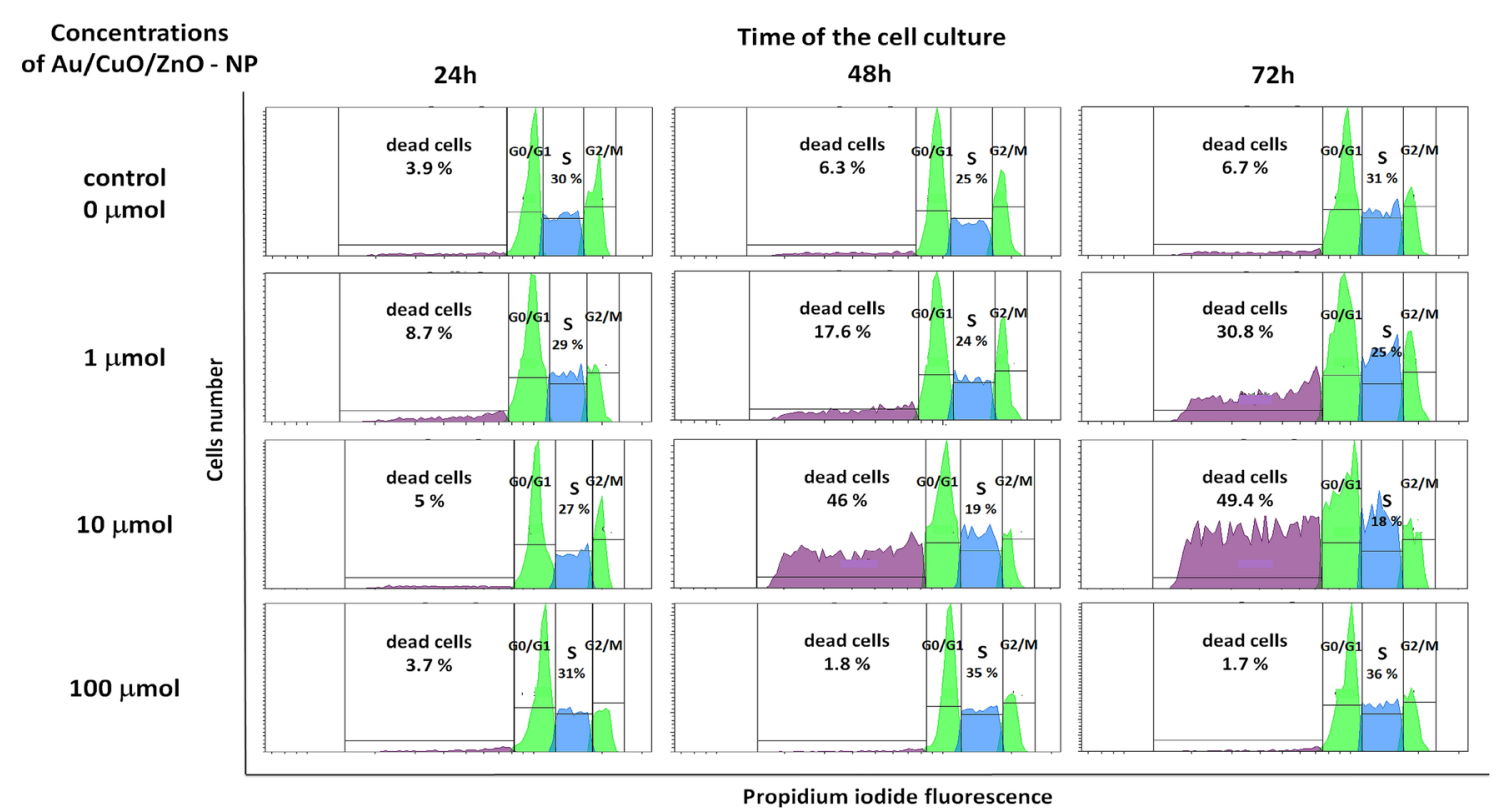

Fig. 10 Histograms of the respective cell cycle phases of the Jurkat cell line cultured for 24,48 and $72 \mathrm{~h}$ in the presence of 1,10 and $100 \mu$ mol of $\mathrm{Au} / \mathrm{CuO} / \mathrm{ZnO}$ nanoparticle complex

During the analysis, it was found that, similarly as in the case of the MTT assay and the Annexin V binding test, the percentage of dead cells increased with the concentration of $\mathrm{Au} / \mathrm{CuO} / \mathrm{ZnO}$ nanoparticles and the duration of culture. After $24 \mathrm{~h}$, the amount of viable cells cultured in the presence of $100 \mu \mathrm{mol}$ of the tested nanoparticles was so low that further analysis was considered unreliable (less than $2 \%$ viable cells). In the remaining samples, the highest percentage of dead cells was observed after applying the tested nanoparticles at the concentration of $10 \mu \mathrm{mol}$. At the 48th hour of culture, cell mortality caused by the tested complexes at the concentration of $10 \mu \mathrm{mol}$ was $46 \%$, and at the 72 nd hour it reached $49 \%$. As regards cells cultured in the presence of $1 \mu \mathrm{mol}$ of the tested nanoparticles, their mortality considerably increased at $72 \mathrm{~h}$ of culture and reached about $31 \%$. For cells treated with nanoparticles, the percentages of cells in the $\mathrm{S}$ phase and the G2/M phase were markedly lower than in the case of control cells. Such a rapid change in proportions between the $\mathrm{S}$ and $\mathrm{G} 2 / \mathrm{M}$ phases and the percentage of dead cells is connected with the observation from the MTT test, which confirmed the high cytotoxicity of the tested nanoparticles, as well as the observation from the Annexin $\mathrm{V}$ binding test, which indicated a sudden death of Jurkat cells. (Fig. 11).

In addition, the study assessed the cell cycle of lymphocytes in PBMC separated from peripheral blood. In the course of the analysis, similarly as in the case of Jurkat cells, the percentage of dead cells among lymphocytes cultured in the presence of the tested nanoparticles was much higher than in the case of cells cultured without the addition of $\mathrm{Au} /$
$\mathrm{CuO} / \mathrm{ZnO}$ nanoparticles. The amount of viable cells cultured at the concentration of $100 \mu \mathrm{mol}$ was very limited, which prevented a credible analysis. The concentration of $10 \mu \mathrm{mol}$ caused a considerable increase in the percentage of dead lymphocytes, i.e. about $20 \%$ after $24 \mathrm{~h}$, and over $30 \%$ after $48 \mathrm{~h}$ of culture (Fig. 12).

\section{Conclusions}

Green chemistry is emerging as a method for synthesizing various chemical products, including nanoparticles. This approach considerably mitigates the threat to the environment as it eliminates hazardous materials from preparation methods that are toxic to humans. Therefore, green synthesis of metal nanoparticles creates a better platform for synthesizing various nanomaterials, including trimetallic nanoparticles. In this work, $\mathrm{Au} / \mathrm{CuO} / \mathrm{ZnO}$ nanoparticles were synthesized using $V$. officinalis extract. The research methods applied in the study, including UV-VIS, FT-IR, TEM and AFM methods, confirmed the presence of spherical trimetallic nanoparticles of about $35 \mathrm{~nm}$. The type of death and the effectiveness of cell elimination depended both on the concentration of the complex and the duration of culture. Within the first $24 \mathrm{~h}$, over $80 \%$ of cells cultured in the presence of $\mathrm{Au} / \mathrm{CuO} / \mathrm{ZnO}$ nanoparticles at the concentration of $10 \mu \mathrm{mol}$ exhibited the signs of late apoptosis, and about $60 \%$ of cells cultured in the presence of $\mathrm{Au} / \mathrm{CuO} / \mathrm{ZnO}$ nanoparticles at the concentration of $100 \mu \mathrm{mol}$ underwent necrosis. The present intense studies that employ metal nanoparticles may lead to the emergence of new medical 


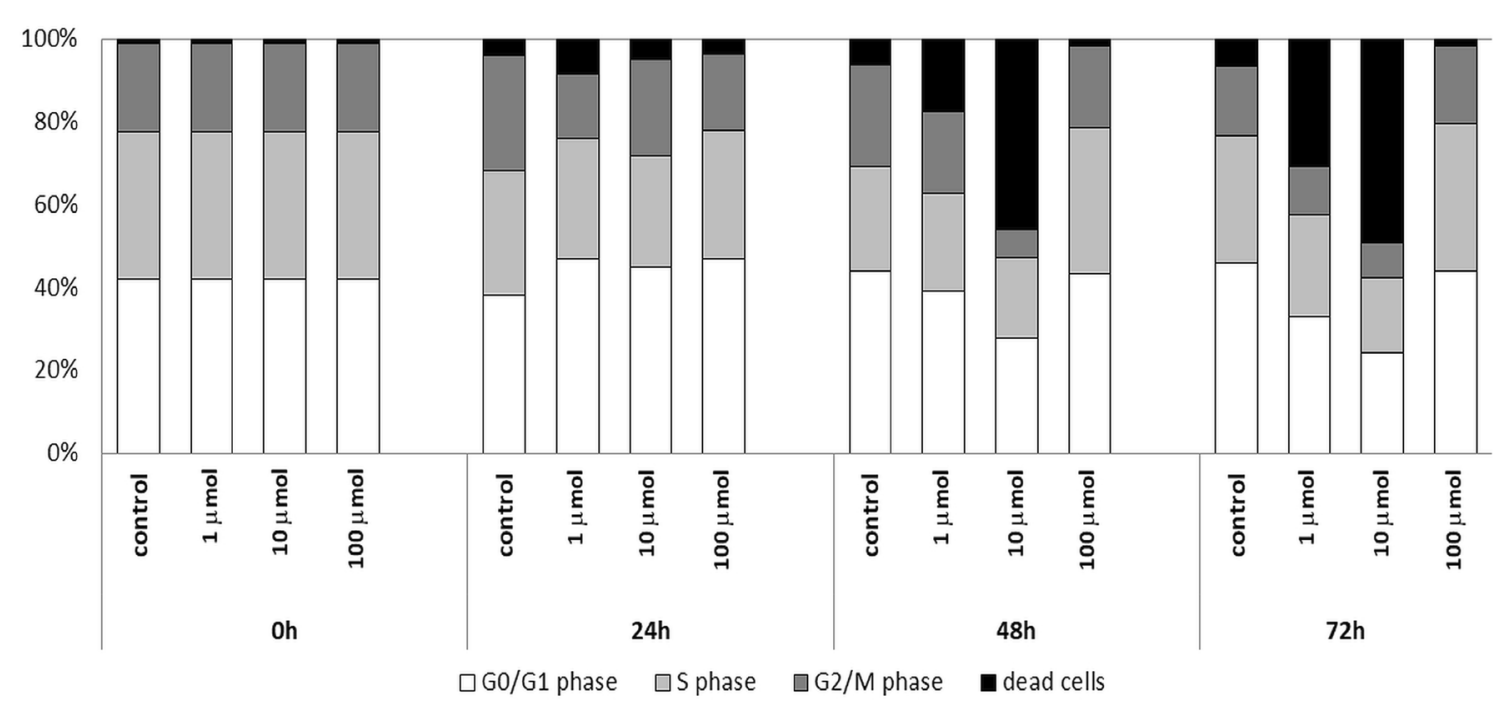

Fig. 11 Percentage of the respective cell cycle phases of Jurkat cells cultured in the presence of 1,10 and $100 \mu \mathrm{mol}$ of $\mathrm{Au} / \mathrm{CuO} / \mathrm{ZnO}$ nanoparticle complex for 24,48 and $72 \mathrm{~h}$

Fig. 12 Percentage of the respective cell cycle phases of lymphocytes in the tested PBMC samples cultured in the presence of 1,10 and $100 \mu \mathrm{mol}$ $\mu \mathrm{mol}$ of $\mathrm{Au} / \mathrm{CuO} / \mathrm{ZnO}$ nanoparticle complex for 24 and $48 \mathrm{~h}$

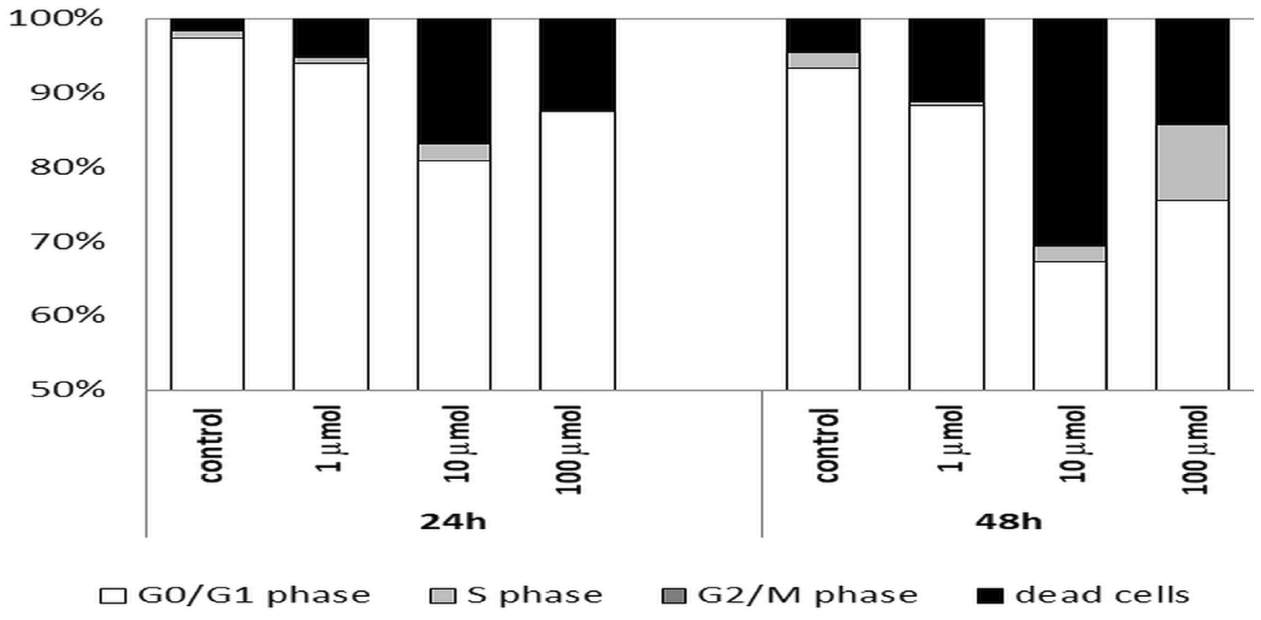

solutions to various kinds of cancer. The conducted studies proved that trimetallic $\mathrm{Au} / \mathrm{CuO} / \mathrm{ZnO}$ nanoparticles obtained from biological synthesis can help to develop effective solutions to combat leukemia.

Acknowledgements Research on synthesis financed from grant for young researchers in 2017 of the Ministry of Science and Higher Education.

\section{Compliance with Ethical Standards}

Conflict of Interest The authors declare that they have no conflict of interest.
Open Access This article is licensed under a Creative Commons Attribution 4.0 International License, which permits use, sharing, adaptation, distribution and reproduction in any medium or format, as long as you give appropriate credit to the original author(s) and the source, provide a link to the Creative Commons licence, and indicate if changes were made. The images or other third party material in this article are included in the article's Creative Commons licence, unless indicated otherwise in a credit line to the material. If material is not included in the article's Creative Commons licence and your intended use is not permitted by statutory regulation or exceeds the permitted use, you will need to obtain permission directly from the copyright holder. To view a copy of this licence, visit http://creativecommons.org/licenses/by/4.0/. 


\section{References}

1. K. Gopinath, S. Kumaraguru, K. Bhakyaraj, S. Mohan, K.S. Venkatesh, M. Esakkirajan, G. Benelli, Green synthesis of silver, gold and silver/gold bimetallic nanoparticles using the Gloriosa superba leaf extract and their antibacterial and antibiofilm activities. Microb. Pathog. 101, 1-11 (2016)

2. J.O. Adeyemi, E.E. Elemike, D.C. Onwudiwe, M. Singh, Bioinspired synthesis and cytotoxic evaluation of silver-gold bimetallic nanoparticles using Kei-Apple (Dovyalis caffra) fruits. Inorg. Chem. Commun. 109, 107569 (2019)

3. A.A. Tsukanov, A.V. Pervikov, A.S. Lozhkomoev, Bimetallic Ag$\mathrm{Cu}$ nanoparticles interaction with lipid and lipopolysaccharide membranes. Comput. Mater. Sci. 173, 109396 (2020)

4. G. Sharma, D. Kumar, A. Kumar, H. Ala'a, D. Pathania, M. Naushad, G.T. Mola, Revolution from monometallic to trimetallic nanoparticle composites, various synthesis methods and their applications: a review. Mater. Sci. Eng. C 71, 1216-1230 (2017)

5. R. Dobrucka, Facile synthesis of trimetallic nanoparticles Au/ $\mathrm{CuO} / \mathrm{ZnO}$ using Vitex agnus-castus extract and their activity in degradation of organic dyes. Int. J. Environ. Anal. Chem. 100, $1-12(2019)$

6. N. Satsangi, Synthesis and characterization of biocompatible silver nanoparticles for anticancer application. J. Inorg. Organomet. Polym. 30, 1907-1914 (2020). https://doi.org/10.1007/s1090 4-019-01372-0

7. P. Kubica, A. Szopa, J. Dominiak, M. Łuczkiewicz, H. Ekiert, Common vervain (Verbena officinalis L.)-botanical characteristics, chemical composition, therapeutic significance, studies on the biological activity and biotechnology researches. Postępy Fitoterapii 19, 183 (2018)

8. D. Paul, S. Mangla, S. Neogi, Antibacterial Study of CuO-NiO$\mathrm{ZnO}$ Trimetallic Oxide Nanoparticle. Mater. Lett. 271, 127740 (2020)

9. R. Wahab, M.A. Siddiqui, Q. Saquib, S. Dwivedi, J. Ahmad, J. Musarrat, H.S. Shin, ZnO nanoparticles induced oxidative stress and apoptosis in HepG2 and MCF-7 cancer cells and their antibacterial activity. Colloids Surf. B Biointerfaces 117, 267-276 (2014)

10. V.S. Saraswathi, J. Tatsugi, P.K. Shin, K. Santhakumar, Facile biosynthesis, characterization, and solar assisted photocatalytic effect of $\mathrm{ZnO}$ nanoparticles mediated by leaves of L. speciosa. J. Photochem. Photobiol. B Biol. 167, 89-98 (2017)

11. K. Ali, S. Dwivedi, A. Azam, Q. Saquib, M.S. Al-Said, A.A. Alkhedhairy, J. Musarrat, Aloe vera extract functionalized zinc oxide nanoparticles as nanoantibiotics against multi-drug resistant clinical bacterial isolates. J. Colloid Interface Sci. 472, 145-156 (2016)

12. K. Elumalai, S. Velmurugan, Green synthesis, characterization and antimicrobial activities of zinc oxide nanoparticles from the leaf extract of Azadirachta indica (L.). Appl. Surf. Sci. 345, 329_ 336 (2015)

13. K. Suwannarat, K. Thongthai, S. Ananta, L. Srisombat, Synthesis of hollow trimetallic $\mathrm{Ag} / \mathrm{Au} / \mathrm{Pd}$ nanoparticles for reduction of 4-nitrophenol. Colloids Surf., A 540, 73-80 (2018)
14. L.D. Martino, G. D’Arena, M.M. Minervini, S. Deaglio, N.P. Sinisi, N. Cascavilla, V.D. Feo, Active caspase-3 detection to evaluate apoptosis induced by Verbena officinalis essential oil and citral in chronic lymphocytic leukaemia cells. Revista Brasileira de Farmacognosia 21(5), 869-873 (2011)

15. P. Kubica, A. Szopa, B. Prokopiuk, Ł Komsta, B. Pawłowska, H. Ekiert, The influence of light quality on the production, of bioactive metabolites-verbascoside, isoverbascoside and phenolic acids and the content of photosynthetic pigments in biomass of Verbena officinalis L. cultured in vitro. J. Photochem. Photobiol. B: Biol. 203, 111768 (2020)

16. J. Guo, M.R. Cahill, S.L. McKenna, C.M. O’Driscoll, Biomimetic nanoparticles for siRNA delivery in the treatment of leukaemia. Biotechnol. Adv. 32(8), 1396-1409 (2014)

17. T.L. Doane, C. Burda, The unique role of nanoparticles in nanomedicine: imaging, drug delivery and therapy. Chem. Soc. Rev. 41(7), 2885-2911 (2012)

18. S. Rajeshkumar, Anticancer activity of eco-friendly gold nanoparticles against lung and liver cancer cells. J. Genet. Eng. Biotechnol. 14(1), 195-202 (2016)

19. Q. Tang, H. Xia, W. Liang, X. Huo, X. Wei, Synthesis and characterization of zinc oxide nanoparticles from Morus nigra and its anticancer activity of AGS gastric cancer cells. J. Photochem. Photobiol. B 202, 111698 (2020)

20. R. Dobrucka, J. Dlugaszewska, M. Kaczmarek, Cytotoxic and antimicrobial effects of biosynthesized $\mathrm{ZnO}$ nanoparticles using of Chelidonium majus extract. Biomed. Microdevices 20(1), 5 (2018)

21. R. Dobrucka, M. Kaczmarek, M. Łagiedo, A. Kielan, J. Dlugaszewska, Evaluation of biologically synthesized, $\mathrm{Au}-\mathrm{CuO}$ and $\mathrm{CuO}-\mathrm{ZnO}$ nanoparticles against glioma cells and microorganisms. Saudi Pharm. J. 27(3), 373-383 (2019)

22. V. Gnanavel, V. Palanichamy, S.M. Roopan, Biosynthesis and characterization of copper oxide nanoparticles and its anticancer activity on human colon cancer cell lines (HCT-116). J. Photochem. Photobiol. B 171, 133-138 (2017)

23. E.E. Elemike, D.C. Onwudiwe, M. Singh, Eco-friendly synthesis of copper oxide, zinc oxide and copper oxide-zinc oxide nanocomposites, and their anticancer applications. J. Inorg. Organomet. Polym Mater. 30(2), 400-409 (2020)

24. M. Fatemi, T. Shomali, S. Nazifi, M. Fazeli, Optimization, characterization and in vivo hepatoprotective effects of gold nanoparticles biosynthesized by eryngium bungei boiss. hydro-alcoholic extract. J. Inorg. Organometall. Polym. Mater. (2020). https://doi. org/10.1007/s10904-020-01569-8

25. M.A. Saidani, A. Fkiri, L.S. Smiri, Copper-doped hybrid Ag X-Au y@ ZnO nanoparticles and their enhanced photocatalytic activities. J. Inorg. Organomet. Polym Mater. 29(4), 1130-1140 (2019)

Publisher's Note Springer Nature remains neutral with regard to jurisdictional claims in published maps and institutional affiliations. 